\title{
技術の話題
}

\section{CAD/CAM と画像ターミナル}

真名垣 昌 夫 $^{+}$

製造業における設計・製造活動の支援を目的とした CAD/CAM システムの技術動向と課題, 特 に図形処理㧍よび CAD/CAM システムにおける設計者とシステムとのインタフェースデバイスで あるグラフィックディスプレイについて述べる。ソフトウェア面では幾何モデルの実用研究, 製品 モデルへの発展が課題であり, ハード面では CAD/CAM ワークステーションが主課題である.

\section{1. まえがき}

生産活動の理想的な形態として, 生産の多様化と自 動化を目指す“ファクトリーオートメーション”への 追求が盛んに行われている. 生産活動の総合的支援を 意図したファクトリーオートメーションの情報処理系 として, 生産管理, 製造ライン制御, 設計支援の各シ ステムの研究, 開発がなされてきた ${ }^{11}$.

生産管理システムは早くから研究開発が行われ, す でに多くの企業で導入され, 実用レベルで効果をあげ ている. 製造ラインの制御も古くは CNC (Computer Numerical Control), 自動化倉庫等が早期に実用化 され, 現在では産業ロボット, メカトロニクスを中心 に発展しつつある。

現在, 最も注目され, 研究開発されているのが, 設 計・製造分野すなわち製品設計・生産製造分野での一 貫したコンピューター利用, “CAD/CAM (Computer Aided Design/Computer Aided Manufacturing) で ある。

CAD は 1960 年代初めに I. E. Sutherland による SKETCHPAD に始まり, グラフィックディスプレイ の応用として，またCAMはAPT (Automatic Programing Tool) に端を発し NC (Numerical Control) プログラミングの分野でと, それぞれ独自に図形処理 として発展した. 1970 年代に入りグラフィックディ スプレイの実用普及が始まり, 図形処理技術の発展と ともに設計支援システムの研究開発が活発化した。そ の結果, 機械図面等の作図や NC プログラムの作成,

†日本電気株式会社 C\&C システム研究所

"Graphic Terminal in CAD/CAM Systems" by Masao Managaki (NEC Corporation, Kawasaki)
出力を狙いとする CAD, CAM システムが実用レベ ルとなり, ターンキーメーカー中心に市場に供され た。

この動きと並行して, 製品や部品の幾何形状を 3 次 元空間でそのまま設計, 表現する幾何モデラーの研究 が進んだ ${ }^{2)}$. 他方, LSI 技術の発展等によりコンピュ ーターグラフィックスの技術も発達し, ラスター形デ ィスプレイに代表される高性能, 安価なディスプレイ 端末が出現し, コンピューターソフト/ハード両面の 技術とも相まって，1980 年を境とし CAD/CAM 統合 システムが実現されるようになった。

本稿では, CAD/CAM システム実現上, 不可欠な 要素技術であるディスプレイターミナルについて, $\mathrm{CAD} / \mathrm{CAM}$ の観点より焦点をあて, ハード/ソフト両 面の技術の現状と課題, エンジニアリングワークステ ーションとしての要請について述べる.

\section{2. $\mathrm{CAD} / \mathrm{CAM}$ システム}

$\mathrm{CAD} / \mathrm{CAM}$ システムの支援対象範囲は, 図 1 に示 すように設計・製造活動を中心とする。この CAD/ CAM システムは, 定形業務から設計者を解放し, よ り創造的活動に従事させるとともに，その作業を支援 することにより, 高い品質の製品設計, 製造を実現す ることを基本的な狙いとしている.

\section{$2.1 \mathrm{CAD} / \mathrm{CAM}$ システムの現状}

現在, 実用レベルの CAD/CAM システムは製図支 援機能に重点を置いた製図システムである。すなわち 設計者が製図板を用いた 2 次元図形を対象とする作業 をグラフィックディスプレイ相手に置きかえたもので ある。

このタイプのシステムは, 既設計結果を用いる編集 


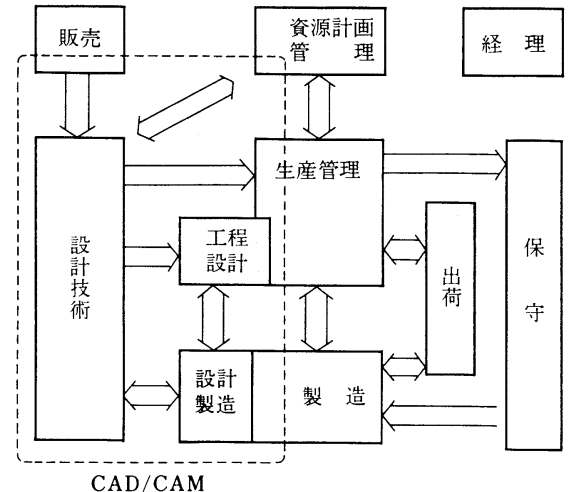

図 1 生産活動と $\mathrm{CAD} / \mathrm{CAM}$

表 1 製図用 CAD システム機能例

\begin{tabular}{|c|c|c|}
\hline \multirow{2}{*}{ 連番 } & コマンド名 & \multirow{2}{*}{ 能 } \\
\hline & 通 称 & \\
\hline 1 & WORK & 作業場の操作 \\
\hline 2 & WINDOW & 画面のコントロール \\
\hline 3 & POINT & 点の作成 \\
\hline 4 & LINE & 線の作成 \\
\hline 5 & CIRCLE & 円の作成 \\
\hline 6 & SPLINE & スプライン曲線の作成 \\
\hline 7 & TYPE & 線種情報操作 \\
\hline 8 & RELIMIT & 図形の伸縮 \\
\hline 9 & CORNER & 面とり \\
\hline 10 & OFFSET & オフセット \\
\hline 11 & DIMENS & 寸 法 \\
\hline 12 & MISC & ユーティリティーコマンド \\
\hline 13 & GROUP & グループ操作 \\
\hline 14 & DRAW & 困面ファイル操作 \\
\hline 15 & PATTERN & パターン, シンボル操作 \\
\hline 16 & INQ & 情報検索 \\
\hline 17 & ANAL & 技術計算 \\
\hline 18 & DELETE & 削除一般 \\
\hline 19 & ATRBT & 属性操作 \\
\hline 20 & AUX & 補助図作成 \\
\hline 21 & PARA & バラメトリック定義，呼び出し \\
\hline 22 & CATALOG & コマンドカタログ作成, 実行 \\
\hline 23 & MTN & メンテナンス一般 \\
\hline 24 & PLOT & プロッター出力 \\
\hline 25 & QUIT & システム終了 \\
\hline 1 & KEYBOARD & キーボード入力要求 \\
\hline 2 & IND & 座標指示要求 \\
\hline 3 & CANCEL & パラメーターキャンセル \\
\hline 4 & $\mathrm{Y} / \mathrm{N}$ & 簡略入力, 処理コントロール \\
\hline 5 & BREAK & コマンドキャンセル \\
\hline
\end{tabular}

設計に有効であり，その機能も表 1 に示すように， 点, 線, 円等の図面構成要素を対話的に迅速に描く機 能が充実している。最近ではデータベース機能を備 え, $\mathrm{CAD}$ 周辺の解析や部品展開, NC プログラミン グ等のアプリケーションと結合した対話形システムも 開発，実用化されている ${ }^{15)}$.

製図中心の $\mathrm{CAD} / \mathrm{CAM}$ システムの開発と並行し て, 設計本来の対象である 3 次元物体を中心とした 3
次元図形処理 “幾何モデラー”の研究開発, 実用化が 試行されている. 製品や部品の厳密な 3 次元モデルを コンピューター内部に作成し, 解析等の設計評価や工 程設計等の CAM との結合を容易にするとともに，設 計者の描くイメージをディスプレイ上で設計する試み である。

\section{$2.2 \mathrm{CAD} / \mathrm{CAM}$ システム構成}

製図システムは, ミニコンピューターに, 数台のグ ラフィックディスプレイを結合したターンキーシステ ムを初めとし, 中・大形コンピューターをホストとし 複数アプリケーションとの結合を目指した汎用システ ムも徐々に開発，実用化された。

さらには単目的のパーソナルコンピューターベース のシステムも実用化され，ミニコンピューターなみの 能力をもつエンジニアリングワークステーションも開 発されている。

ディスプレイデバイスは最近ほとんどラスタータイ プが用いられ，ディスプレイ側に数メガバイトのメモ リー, ベクトル演算等のファームウェアを有するイン テリジェントディスプレイが使用されている．入力機 器はキーボードやライトペン, マウス, タブレット等 のポインティングデバイスが中心であり，操作性での 一工夫が必要である。

\section{CAD/CAM 図形処理と画像ターミナル}

$\mathrm{CAD} / \mathrm{CAM}$ システムにとり, 設計・製造対象物を表 現する製品モデルは基本要素であり，研究段階にあ る. 現在，その中核となる形状を表現する幾何モデル 技術が碓立しつつある。

\section{1 幾何モデル，図形処理}

$\mathrm{CAD} / \mathrm{CAM}$ に扔ける図形処理の基盤は形状を作り

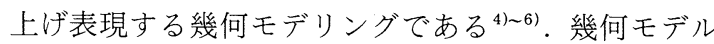
には, 表 2 に示すようにワイヤフレーム, サーフェイ ス，ソリッドの 3 種のモデルがある．処理速度の面か ら, ワイヤフレーム, サーフェイスモデルを用いたシ ステムが商用化されている.

しかし，これらのモデルは物体表現上のあいまい さ, 情報欠損などのモデルの厳密性に欠けるため, 厳 密なモデルであるソリッドモデルが CAD/CAM の中 核幾何モデルとして注目され，表 3 に示すように数多 く研究開発されている6). ソリッドモデルの多くは多 面体や解析面で構成したプリミティブと呼ぶ基本形状 の組合せ（集合演算）で 3 次元形状を構築するモデラ 一が多い. 図 2 に, 2 次元形状の組合せから 3 次元形 状を生成, さらに組合せて所要の物体を設計する過程 を示す。 
表 2 幾何モデルの特徵

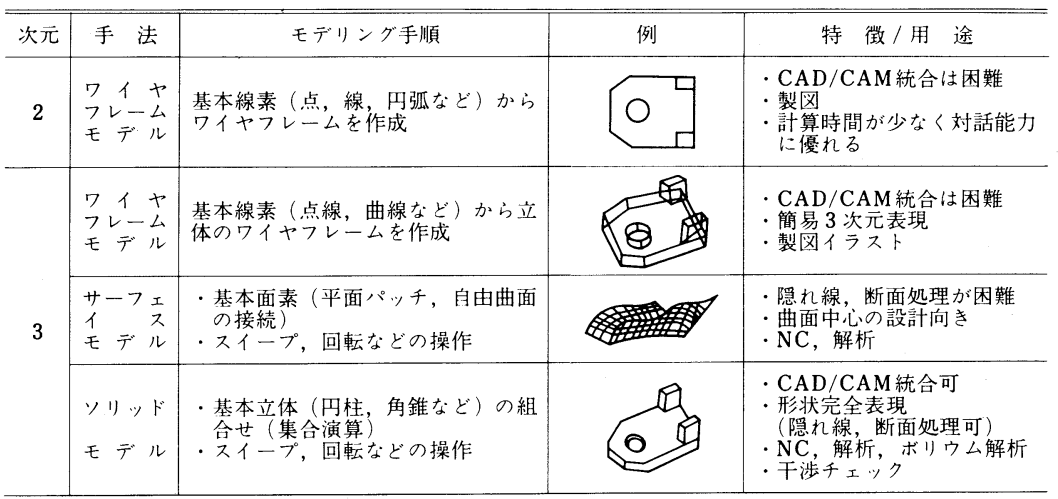

表 3 幾何モデル

\begin{tabular}{|c|c|c|c|}
\hline システム & プリミティ ブ & 開 発 機 関 & \\
\hline $\begin{array}{l}\text { SHAPES } \\
\text { TIPS }\end{array}$ & $\begin{array}{l}\text { 円錐, 円筒, 球, 楕円曲面 } \\
\text { 平面, 円筒, 直方体, 球, フィレット, 平方体, 回転体, 他 } \\
\end{array}$ & $\begin{array}{l}\text { DRAPER研究所 } \\
\text { 北海道大学 }\end{array}$ & $\begin{array}{l}(\text { アメリカ }) \\
(\text { 日 } \quad \text { 本 })\end{array}$ \\
\hline $\begin{array}{l}\text { GDP/GRIN } \\
\text { PADL-1 } \\
\text { PADL- } 2 \\
\text { SYNTHAVISION }\end{array}$ & $\begin{array}{l}\text { 直方体, 円筒, 円錐, エッジ, 半球, 掃引体, 回転体 } \\
\text { 直方体, 円筒のみ } \\
\text { 直方体, 円筒, トーラス, 円錐, 球 } \\
\text { 平行六面体, エッジ, 円筒, 棈円錐台, 自由曲面, 他 } \\
\end{array}$ & $\begin{array}{l}\text { IBM } \\
\text { ROCHESTER大学 } \\
\text { ROCHESTER大学 } \\
\text { MAGI } \\
\end{array}$ & $\begin{array}{l}(\text { (アメリカ }) \\
(\text { アメリカ }) \\
\text { (アメリカ }) \\
\text { (アメリカ })\end{array}$ \\
\hline GM solid & 直方体, 円筒, 円錐, 球, 自由曲面 & GENERAL MOTORS & (アメリカ) \\
\hline $\begin{array}{l}\text { U. M. /BORKIN } \\
\text { BUILD-2 } \\
\text { CADD } \\
\text { COMPAC } \\
\text { DESIGN } \\
\text { EUCLID } \\
\text { EUKLID } \\
\text { GEOMAP } \\
\text { GEOMOD } \\
\text { GLIDE } \\
\text { MEDUSA } \\
\text { PROREN-2 } \\
\text { ROMULUS } \\
\text { SOLID DESIGN } \\
\text { UNIGRAPH } \\
\text { 3DFORM }\end{array}$ & $\begin{array}{l}\text { 直方体, エッジ, 四面体, 円筒, 掃引体, 回転体, 他 } \\
\text { 直方体, 円筒, APT-like } \\
\text { エッジ, 正多面体, 直方体 } \\
\text { 点, 面, 体, Bezier 曲面 } \\
\text { 直方体, 円筒, 円錐, 多角錐, 掃引体 } \\
\text { 円筒, 円錐 } \\
\text { 平面, 円筒, 円錐, エッジ, フィレット }\end{array}$ & $\begin{array}{l}\text { MICHIGAN大学 } \\
\text { CAMBRIDGE大学 } \\
\text { MCAUTO } \\
\text { BERLIN工科大学 } \\
\text { MDSI } \\
\text { MATRA/DATAVISION } \\
\text { FIDES } \\
\text { 東京大学 } \\
\text { SDRC } \\
\text { CARNEGIE MELLON大学 } \\
\text { CIS } \\
\text { RUHR大学 } \\
\text { SHAPEDATA } \\
\text { COMPUTER VISION } \\
\text { MCAUTO } \\
\end{array}$ & 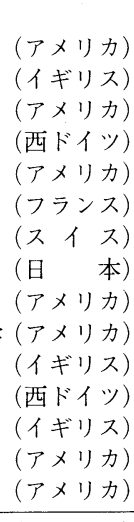 \\
\hline $\begin{array}{l}\text { AD2000 } \\
\text { ANVIL } 4000 \\
\text { ALPHA-1 } \\
\text { CATIA }\end{array}$ & $\begin{array}{l}\text { スプライン, 球, 円筒, トーラス, 円錐面, 回転体, 他 } \\
\text { スプライン, フィレット, 六面体, 掃引体, 自由曲面, 他 } \\
\text { スプライン } \\
\text { 立方体, 平行六面体, 球, 円筒, 円錐, トーラス }\end{array}$ & $\begin{array}{l}\text { MCS } \\
\text { MCS } \\
\text { UTA大学 } \\
\text { DASSULT }\end{array}$ & $\begin{array}{l}\text { (アメリカ) } \\
\text { (アメリカ) } \\
\text { (アメリカ) } \\
\text { (フランス })\end{array}$ \\
\hline
\end{tabular}

自由曲線, 曲面の設計に対しては, パッチ方式で曲 面を補間してゅく Coons らの双 $n$ 次パッチに代表さ れる内挿法から，必ずしも曲面上にない点（制御点） をサンプリングし，それらの点列から所要の曲面を生 成してゆく BezierやB-spline に代表される近似法へ と変化してきている7 . 特に形状の表現能力, 局所変 更能力に優れている B-spline 曲面の研究開発が盛ん である. 写真 1 に B-spline 関数を用いた曲面生成例 を示す。

また,これらの幾何モデラーで形成された 3 次元形
状に対して, 現実感を付与する研究も数多く行われて いる ${ }^{718)}$.なかでもラスタースキャン形ディスプレイ に適した隠れ面消去アルゴリズムとしてスキャンライ ン方式がある ${ }^{9}$.これは上方のスキャンラインから下 方へ 1 本のスキャンライン上で, 隠れ面の検出, 消 去, 可視面の表示を行うアルゴリズムであり, ディス プレイのピクセル毎に表示を行う.

写真 2 のように表示の現実感を求め，このアルゴリ ズムの上に光の反射等をモデル化した照明モデル等 ${ }^{101}$ を付与し表現する研究がコンピューターグラフィック 


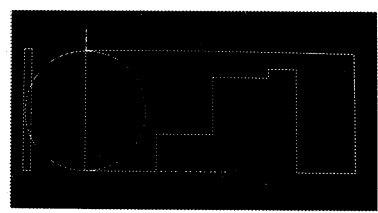

(a) $\mid 2$ 次元集合演算

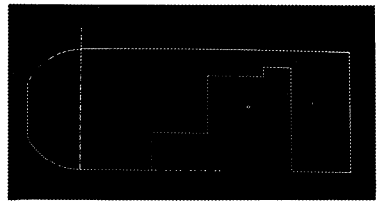

(b) $\mid$ スイープ

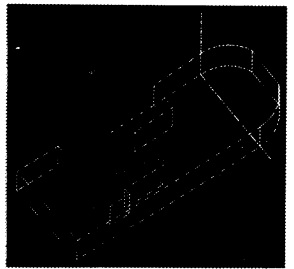

(c)

図 2 ソリッドモデル構築例
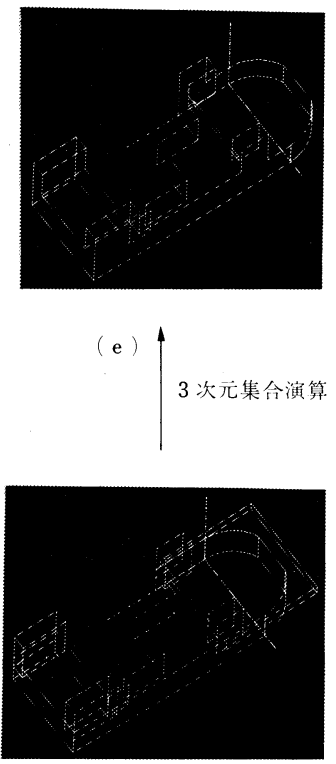

(d)

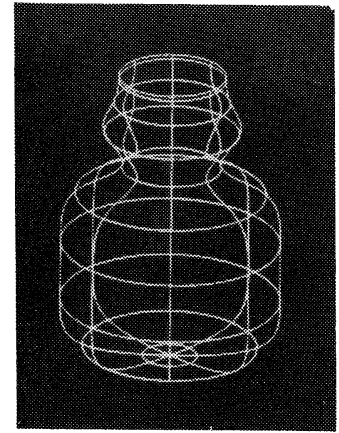

(a ) 曲面作成例

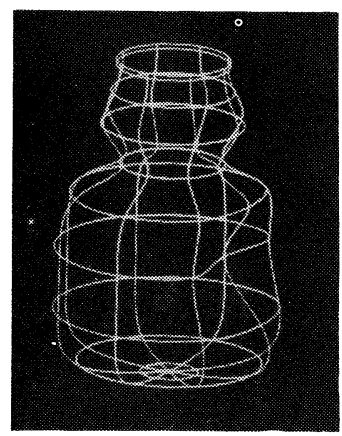

(b) 局所修正例

写真 1 B スプライン関数曲面生成例

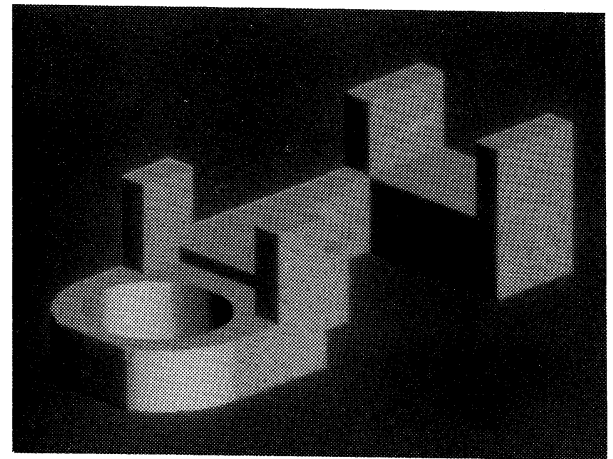

写真 2 ジューディング絵

スの分野の研究として行われている.

\section{$3.2 \mathrm{CAD} / \mathrm{CAM}$ グラフィックターミナル}

設計が物体の形状を主として扱う作業であることか ら, 人間とコンピューターとのインタフェースデバイ スとしてグラフィックディスプレイが用いられてい る ${ }^{1112)}$. 表 4 に示すように性能, コス卜面で優れてい るラスタータイプディスプレイが主流となりつつあ る。また表 5 の性能諸元に示すように，ディスプレイ デバイス側にインテリジェント機能を付加し，ホスト コンピューターとの機能，負荷分担を図るとともに， 対話処理に耐える性能を実現する動きがある。 
表 4 グラフィックディスプレイの特徴

\begin{tabular}{|c|c|c|c|}
\hline & \multirow{2}{*}{ ストレージ } & \multirow[t]{2}{*}{ リフレ } & ッ シ ュ \\
\hline & & & ラスター \\
\hline $\begin{array}{ll}\text { 線 質 } \\
\end{array}$ & 良 & 高線質 & 斜線が階段状 \\
\hline 分 解 能 & $4,000 \times 4,000$ & $2,000 \times 2,000$ & $1,000 \times 1,000$ \\
\hline 表示ベクトル数 & 無制限 & $15,000 \sim 50,000$ 本 & 無制限 \\
\hline 表示の明るさ & 暗 い & 良 & 明るい \\
\hline カ ラ - & 2色まで & 4 色まで & 非常に多い \\
\hline 塗りつぶし & 可 & 不 可 & 可 \\
\hline 動 的 表 示 & 不 可 & 高 速 & 普 通 \\
\hline 知 的 機 能 & 低 & 高 & 高 \\
\hline 価 & 600 万〜 1,000 万 & 1,200 万 2,300 万 & 400 万 1,000 万 \\
\hline
\end{tabular}

表 5 ラスタースキャン形ディスプレイ主要性能

\begin{tabular}{|c|c|}
\hline 諸 元 & 内 容 \\
\hline デイスプレイモニター & $\begin{array}{l}20 \text { インチ, } 60 \mathrm{~Hz}(30 \mathrm{~Hz}, 1: 2 \text { イ } \\
\text { ンタレース) }\end{array}$ \\
\hline 表示分解能 & $1,280 \times 1,024,1,400 \times 1,024$ \\
\hline カラー & $\begin{array}{l}\text { カラーパレット： ～32,768色 } \\
\text { 同時表示 : 16〜4,096 }\end{array}$ \\
\hline プロセッサ & 16 ビット, 32 ビット \\
\hline メモリー & $256 \mathrm{~KB} \sim 8 \mathrm{MB}$ \\
\hline フレームメモリー & $4 \sim 20$ プレーン $^{\circ}$ \\
\hline 速 度 & $\begin{array}{l}\text { ショートベクトル }: 10^{5} \text { 本 } / \mathrm{sec} \\
\text { ピッキング }: 10^{4} \text { 本 } / \mathrm{sec}\end{array}$ \\
\hline デー夕構造 & 階層構造 \\
\hline 他 & $\begin{array}{l}3 \text { 次元ベクトル演算, 日本語処理, } \\
\text { 隠面, シェーディング, 奴つぶし, } \\
\text { ローカルインタラクション (ポジシ } \\
\text { ヨニング, 回転 etc) }\end{array}$ \\
\hline
\end{tabular}

\section{$3.3 \mathrm{CAD} / \mathrm{CAM}$ ワークステーション}

32 ビットマイクロプロセッサは端末のイメージを 変え, スーパーミニコンピューターなみの処理性能を もつ廉価な高機能な CAD/CAM ワークステーション の実現が図られつつある. 図 3 に示すような構成をも つ CAD/CAM ワークステーションが備えるべき機能 を以下に列挙する。

（1）互 換 性：標準 OS (ONIX など), 標準 バス（例 MULTI バス）

（2）高 性 能：32ビットマイクロプロセッ

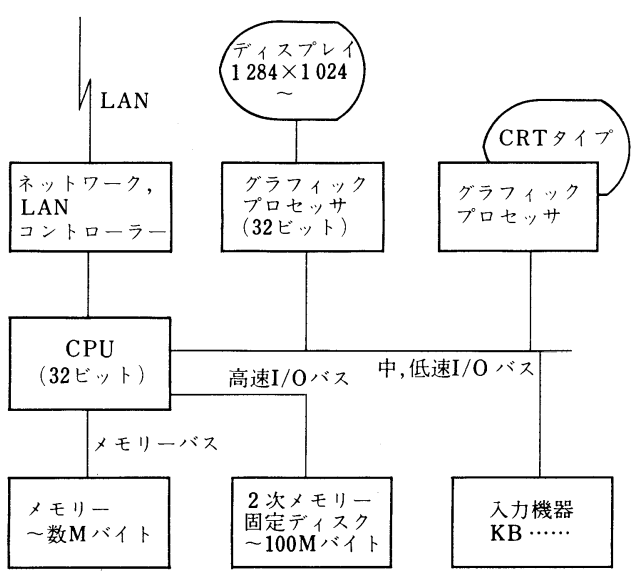

図 $3 \mathrm{CAD} / \mathrm{CAM}$ ワークステーション例

（3） OS : マルチタスク/シングルユー ザー, 同一画面上で多くの視 点を与えるマルチウィンド ウ，仮想記憶

（4）言 語：高水準言語（FORTRAN, C $\cdots)$

（5）基本ソフト：データベース管理システム, グラフィック標準 $(\mathrm{GKS}, \cdots)$

（6）通信機構：ローカルエリアネットワーク (イーサネット他) $\mathrm{RS} 232 \mathrm{C} / 449$ などの接続イン タフェース

（7）メモリー：主記憶…数メガバイト 2 次記憶…固定ディスク, $\cdots$

（8） 入力デバイス：キーボード, タブレット, ポインティングデバイス, $\cdots$

（9）他ソフト：テキストエディター,グラフ イックエディター, デバッキ ングツール

このような $\mathrm{CAD} / \mathrm{CAM}$ ワークステーションを想定 したときの問題は, ホストコンピューターとワークス テーションの機能分担の決定である. 図4 亿その境界 案を示す。ワークステーションはユーザー側の要求か

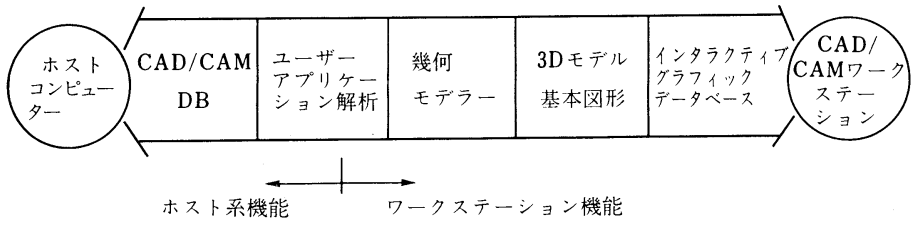

図 4 ホストコンピューター/ワークステーション機能分散 
ら現れたものであり，将来の $\mathrm{CAD} / \mathrm{CAM}$ デバイスの 一方向を示したものであるといえる ${ }^{1314)}$.

\section{4 グラフィック標準}

$\mathrm{CAD} / \mathrm{CAM}$ システムにおいては，目的，環境に応 じて多種多様なディスプレイデバイスを使用する．こ のことから, ハードウェアに従属しないシステムの互 換性, 特にプログラムやデータの互換性が問題とな る。

このハードウェアや言語等に独立なグラフィックス 標準の作業が ISO (International Standard Organization) や ANSI (American National Standards Institute）を中心に進められている。その代表的なもの が GKS (Graphische Kernsysteme), PHIGES (Programer's Hierarchical Interactive Graphics Standard), IGES (Initial Graphics Exchange Specification) である.

ANSI 提案の CORE の機能をも吸収しつつある. GKS は，言語の規定ではなくグラフィックソフトウ エアの持つべき機能を規定しており，図形のもつ構造 をアプリケーションの問題としてとらえている． 3 次 元への拡張は GKS-3D として標準化作業が進められ ている.

PHIGES は, グラフィックサポートシステム, 応 用プログラムとのインタフェースにおける機能仕様を 定める. 特にグラフィックデータの変更, 幾何学的/ 階層的な関連, それらの動的扱いを重視し, 従来アプ リケーション側で行っていた機能を基本図形処理とし てとりこもうとしている.

IGES は, 多くのターンキーシステム間のデータ交 換を目指したものである. 現在ではワイヤフレームモ デルを対象に作業が進められており, 今後はソリッド モデルへも拡張する予定である.

上記以外にもグラフィック関係の標準規格作業が進 められており, まだ数多くの問題点をかかえている 5).

\section{4. むす び}

$\mathrm{CAD}$ と CAM は, グラフィックディスプレイの出 現により研究が始まり, その発展とともに CAD, CAM 技術も進展し, 一部では実用化されている. 特 にラスタースキャン形ディスプレイの出現, 高性能マ イクロプロセッサの出現は, CAD, CAMに扔る図
形処理技術の発展，その実用化を急速なものとし，デ ータベース等のコンピューターソフトの発展にもささ えられ, 統合 $\mathrm{CAD} / \mathrm{CAM}$ システムを現実のものとし ている。

今後, グラフィックターミナルは, $\mathrm{CAD} / \mathrm{CAM}$ 分 野に抒ける設計者・システムインタフェースの基本デ バイス, 装置として, 廉価・高性能化, 高い操作性等

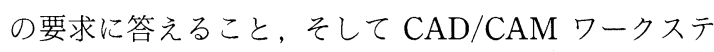
ーションの実現が重要な課題であると考える.

(昭和 59 年 7 月 30 日受付)

\section{〔参 考 文 献〕}

1）木村文彦：“FAにおける情報処理技術の役割”，情報処理， 25, 4, pp. 283-295 (Apr., 1984)

2) R. Hillyard: "A Taxonomy of Engineering Geometric Modelling Systems", Conf. CAD/CAM Technology in Mech. Eng., pp. 331-339 (1982)

3) A. A. G. Requicha: "Representations for Rigid Solids", Computing Surveys, 12, 4, pp. 437-464 (Dec., 1980)

4) M. Managaki : "Multi-layered Database Architecture for CAD/CAM Systems", IFIP Working Conf. CAD Data Base, pp. 281-294 (1982)

5）穂坂衛：“コンピューターグラフィックス標準化の動向”, 情 報処理学会, グラフィックスと CAD 研究会, 12-5 (Mar., 1984)

6）“CAE に関する調查研究報告”，(財) 日本情報処理開発協会, 56-R 004 (Mar., 1982)

7) R.F. Riesenfeld: "Application of B-Spline Approximation to Geometric Problems of Computer-Aided Design", Ph. D. Thesis Univ. of Utah. UTEC-CSC-73-R6 (Mar. 1973)

8) W. M. Newman, R. F. Sproull : "Principle of Interactive Computer Graphics", McGraw-Hill (1979)

9) S. D. Roth : "Ray Casting for Modelling Solids", Comp. Graphics and Image Processing, 18 (1982)

10) Bui Tuong Phong: "Illumination for Computergenerated Images”, Univ. Utah UTEC-CSc-73-129 (1973)

11) R. J. Hubbold : "Computer Graphics and Displays", Computer Aided Design, 16, 3, pp. 127-133 (May, 1984)

12) P. Sniger: "Mid-range CAD/CAM/CAE Systems Dominate Graphic Display Terminals", Mini-Micro Systems, pp. 224-231 (July, 1984)

13) M. R. Martin : "Work Station Morket Issues", IEEE, CG\&A-4, 4, pp. 77-80 (Apr., 1984)

14) E. L. Busick: "Changing Resource Mix Affects Future Role of CAD/CAM Workstations", Comp. Technology Review, 4, 1, pp. 143-155 (Winter, 1984)

15）真名垣ほか：“CAE-2 のシステム”, NEC 技報, 36, 6, pp. 77 $-85(1983)$

16）真名垣,川越ほか：“3 次元形状処理システムの構想と実現”, 情報処理学会, グラフィックスと CAD 研究会 (June, 1984)

17) M. Managaki, K. Kawagoe: "A Parametric Man/ Machine Interaction on with Semantic Data", Comp. and Graphics, 7, 3-4, pp. 233-242 (1983)

18) S. Kuno, M. Managaki, et al: "ATHENA : A Knowledge Based CAD System”, ISDS, pp. 32-37 (July, 1984) 